\title{
Krystyna Moszkowicz
}

Uniwersytet Ekonomiczny we Wrocławiu

e-mail: krystyna.moszkowicz@ue.wroc.pl

\section{Boguslaw Bembenek}

Politechnika Rzeszowska

e-mail: bogdanb@prz.edu.pl

\section{OTWARTE INNOWACJE}

JAKO STRATEGICZNE WYZWANIE W ZARZĄDZANIU KLASTRAMI KREATYWNYMI

\section{OPEN INNOVATIONS AS A STRATEGIC CHALLENGE IN THE MANAGEMENT OF CREATIVE CLUSTERS}

DOI: $10.15611 /$ noz.2016.4.07

JEL Classification: L14, L15, L17, L21, L22, L26, M11, M21, O31, O32, P13

Streszczenie: Rozważania o wartości otwartych innowacji w zarządzaniu rozwojem klastrów kreatywnych rozpoczęto od charakterystyki sektora kreatywnego. W artykule podkreślono, że sektor ten - jako wewnętrznie zróżnicowany - ma strategiczne znaczenie zarówno dla polskiej, jak i europejskiej gospodarki, gdyż stanowi solidny filar gospodarki opartej na wiedzy. Następnie zwrócono uwagę na znaczną różnorodność definicji klastra kreatywnego, podkreślając, że sytuacja ta utrudnia precyzyjne dokonywanie badań i analiz. Wskazano na potencjał rozwoju klastrów kreatywnych i ich rolę w pozyskiwaniu i rozwoju kapitału ludzkiego, kapitału społecznego oraz przyciąganiu zainteresowania inwestorów strategicznych czy kształtowaniu atrakcyjnej przestrzeni dla rozwoju innowacji wartości. W trzeciej części artykułu scharakteryzowano istotę koncepcji otwartych innowacji oraz potencjalną wartość implementacji tej koncepcji w zarządzaniu rozwojem klastrów kreatywnych. Rozważania naukowe zawarte w niniejszym artykule prowadzono, opierając się na wynikach badań teoretycznych i badań typu desk research.

Słowa kluczowe: klaster, zarządzanie, kreatywność, innowacja, rozwój.

Summary: Scientific discussion on the value of open innovation in managing the development of creative clusters starts with the characteristics of the creative sector. The article stresses that this internally diverse sector is of strategic importance for Polish and European economies as it constitutes a solid pillar of knowledge-based economy. Subsequently, it presents definitions of the creative clusters, emphasising that their variety hampers accurate research and analysis. There is indicated the development potential of creative clusters and their role in the acquisition and development of human and social capital and attracting the interest of strategic investors and the creation of an attractive environment for the development of value innovation. The third part of the article characterizes the essence of the concept of open innovation and the 
Krystyna Moszkowicz, Bogusław Bembenek

potential value of the implementation of this concept in managing the development of creative clusters. Scientific considerations contained in this article are based on the results of theoretical and desk research.

Keywords: cluster, management, creativity, innovation, development.

\section{Wstęp}

Obecnie ciągle aktualnym tematem dyskusji naukowych jest znaczenie sektora kreatywnego i funkcjonujących na bazie jego podmiotów - klastrów kreatywnych dla rozwoju gospodarki opartej na wiedzy. Ten model gospodarki, która w głównej mierze cechuje się silnym dążeniem do stymulowania swobodnego transferu wiedzy pomiędzy środowiskiem nauki i biznesu, dążeniem do kreowania innowacji wartości, stwarza współcześnie menedżerom klastrów kreatywnych wciąż nowe wyzwania strategiczne. Jednym $\mathrm{z}$ nich jest opracowywanie innowacyjnych rozwiązań w klastrze zgodnie z filozofią otwartych innowacji.

Kluczowym elementem rozwoju klastrów kreatywnych jest intensyfikacja podejmowanych działań zarządczych w tych strukturach, zmierzających w kierunku stymulowania i rozwoju współpracy w relacjach: biznes - nauka - administracja publiczna - instytucje otoczenia biznesu. Turbulentne otoczenie sprawia, że szczególnie w sektorze kreatywnym niezwykle istotna jest szybkość i elastyczność w zakresie zarządzania wiedzą, innowacją i rozwojem. Tym samym poszczególne podmioty sektora kreatywnego nie mogą jedynie bazować na własnych zasobach, indywidualnie prowadzonych badaniach, ale powinny być w coraz większym stopniu otwarte na potencjał kreatywny swoich partnerów, by móc czerpać korzyści z efektu twórczej synergii. Bardzo ważna jest w tym przypadku świadomość wartości współpracy z różnorodnymi partnerami w sektorze kreatywnym. Wspólne inicjatywy proinnowacyjne mogą prowadzić do konkretnych projektów, których dany podmiot tego sektora nie mógłby zrealizować w takim wymiarze i charakterze, bazując jedynie na własnych zasobach.

Celem artykułu jest charakterystyka wartości otwartych innowacji w procesie zarządzania klastrami kreatywnymi. Ponadto zamiarem badawczym jest analiza koncepcji otwartych innowacji z punktu widzenia współczesnego wyzwania w zarządzaniu rozwojem klastrów kreatywnych. Tak sformułowany cel artykułu wiąże się z faktem, że klastry kreatywne funkcjonujące w sektorach kreatywnych, oparte na wielokierunkowych interakcjach angażujących różnych interesariuszy, doceniane są w krajach rozwiniętych już od ponad kilkunastu lat. Jednak sama natura tego problemu badawczego nie jest jeszcze w pełni poznana na gruncie nauk o zarządzaniu, przez co wszelkie próby bliższej jego charakterystyki pozwalają na ograniczenie luki wiedzy w tym zakresie. 


\section{Sektor kreatywny jako fundament aktywności klastrów kreatywnych}

Precyzyjne definiowanie sektora (przemysłu) kreatywnego jest niemalże niemożliwe ze względu na różne postrzeganie firm i działań kreatywnych, elastyczne granice sektora kreatywnego, a także z uwagi na fakt, że podmioty tego sektora działają na styku aktywności kulturalnej i kreatywnego biznesu. Granice tego sektora są wyznaczane m.in. przez właściwe danej sytuacji i danym potrzebom rozumienie istoty kreatywności, innowacji, własności intelektualnej, produktu kreatywnego. Tym samym funkcjonujące w teorii i praktyce gospodarczej definicje sektora kreatywnego wskazują na jego duże zróżnicowanie wewnętrzne. W literaturze przedmiotu najczęściej sektor kreatywny definiowany jest jako [Grochowski 2010, s. 19-20; Grochowski i in. 2012, s. 11]:

- sektor gospodarki, który wytwarza produkty i generuje miejsca pracy przez wykorzystanie własności intelektualnej;

- sektor gospodarki, w skład którego wchodzą te dziedziny aktywności, które używają kultury jako wartości dodanej w produktach pozakulturalnych;

- sektor gospodarki, który złożony jest z czterech podstawowych komponentów, takich jak: usługi kreatywne (np. agencje reklamowe, architekci, projektanci, fotografowie, konsultanci oprogramowania), treści kreatywne (transmisje na żywo, firmy nagraniowe, wydawcy książek i czasopism, studia filmowe, wydawcy gier, producenci muzyczni, producenci programów telewizyjnych), doznania kreatywne (sprzedaż konsumentom prawa doświadczenia lub uczestniczenia na żywo w określonych widowiskach, przedstawieniach, występach, pokazach plenerowych), indywidualne wytwory kreatywnych jednostek (sztuki plastyczne, rękodzieło i rzemiosło artystyczne);

- sektor gospodarki, obejmujący: działalności twórcze (definiowane przez charakter nakładów pracy), działalności związane z prawami autorskimi (definiowane przez charakter tworzonych zasobów i rezultatów pracy), działalności kulturalne (definiowane przez publiczny charakter funkcji i źródeł finansowania), działalności związane z obróbką cyfrową (definiowane przez kombinację nowoczesnej technologii z działalnością twórczą).

Współcześnie sektor kreatywny uznawany jest za sektor o strategicznym znaczeniu w procesach rozwoju gospodarczego i kształtowania konkurencyjności w skali lokalnej, regionalnej, krajowej i międzynarodowej. Fundamentem jego rozwoju jest bez wątpienia kapitał intelektualny, w tym kapitał ludzki i relacyjny. Ponadto sektor ten charakteryzuje się [Wróbel 2013, s. 117-122; Kotylak 2013b, s. 157-158; Szultka 2012, s. 17, 59; Bagwell 2008, s. 33-34]:

- wysokim poziomem innowacyjności i dużym potencjałem wzrostu,

- wysokim poziomem niepewności, szczególnie w przypadku popytu na wytwarzane dobra i świadczone usługi, 
- rozwojem, który nie wynika ściśle ze standaryzacji i obniżania kosztów produkcji, a ze zwiększania jakości w zaspokajaniu potrzeb kulturalnych konsumentów, którzy mają zróżnicowane potrzeby i oczekiwania,

- dużą różnorodnością produktów kreatywnych, które różnią się od siebie jakością i niepowtarzalnością, przez co wymagają różnych kompetencji,

- trwałością niektórych produktów związaną z ochroną praw autorskich, co pozwala ich twórcom lub wykonawcom czerpać długotrwałe korzyści,

- wewnętrzną koordynacją działalności kreatywnej ze względu na krótkie ramy czasowe jej realizacji oraz konieczność ochrony własności intelektualnej,

- wysoką kapitałochłonnością nowych inwestycji i potrzebami finansowymi,

- utrudnionym dostępem podmiotów sektora do podstawowych źródeł finansowania inwestycji o wysokim poziomie ryzyka,

- wykorzystywaniem instrumentów finansowych wysokiego ryzyka, w tym venture capital oraz finansowania społecznościowego (crowdfunding).

Sektor kreatywny stanowi solidny fundament rozwoju klastrów kreatywnych. Członkowie tych klastrów często funkcjonują w tzw. przestrzeniach kreatywnych. Tego typu środowisko, stymulujące kreatywność jednostek i zespołów poprzez sze-

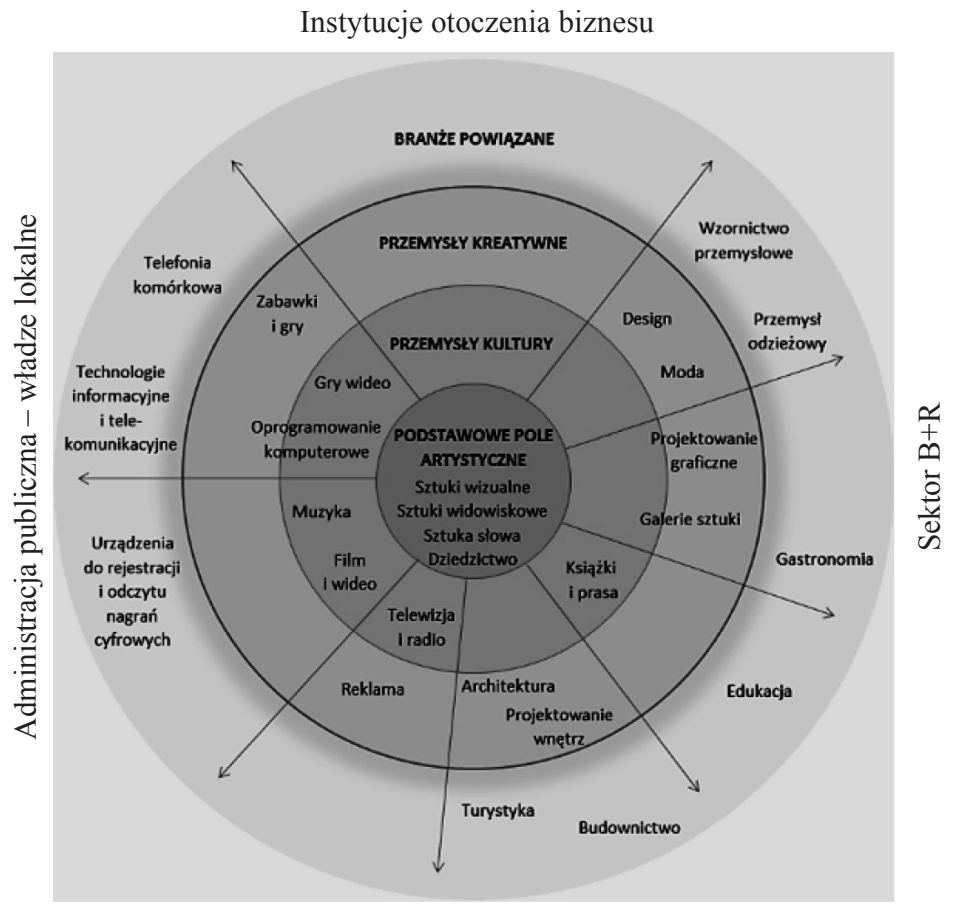

Koordynator klastra (organizacja klastrowa)

Rys. 1. Model klastra kreatywnego

Źródło: opracowanie na podstawie [Obłąkowska-Kubiak 2014, s. 37]. 
roki wachlarz pozytywnych bodźców, powstaje zazwyczaj w przestrzeni miejskiej, komercyjnej i/lub publicznej. Zlokalizowani w niej członkowie klastra kreatywnego (rys. 1) i zdarzenia związane bezpośrednio z ich działalnością systematycznie zachęcają do sieciowania, aktywnego korzystania z szerokiej oferty usług i produktów kreatywnych, włączania się do współtworzenia nowych rozwiązań kreatywnych, wyprzedzających oczekiwania i potrzeby klientów [Szultka 2012, s. 55].

Aby przestrzeń kreatywna była nasycona podmiotami sektora kreatywnego i sprzyjała rozwojowi działalności kreatywnej, niezbędne są swobodne kontakty osobiste i partnerstwo w relacjach formalnych i nieformalnych. Poprzez łączenie podmiotów i ich doświadczeń, wiedzy, kreatywności, z wykorzystaniem zaufania, jakim darzą się partnerzy, istnieje realna możliwość tworzenia nowych rozwiązań z uwzględnieniem odmiennych perspektyw i poglądów [Dudek-Mańkowska i in. 2012, s. 148, $155]$.

Z przeprowadzonych dotychczas badań i analiz dotyczących kondycji polskiego sektora kreatywnego wynika, że niezależnie od regionu czy konkretnego miejsca zakorzenienia kluczowych podmiotów tego sektora istnieją podobne bariery ograniczające jego sprawny rozwój. Tym samym dla poprawienia jego kondycji niezbędna jest jego wewnętrzna integracja, dalsza specjalizacja, stałe podnoszenie kompetencji biznesowych twórców, wzmocnienie marketingu produktów kreatywnych oraz wspieranie podmiotów kreatywnych przez władze lokalne i instytucje otoczenia biznesu w formie specjalnie przygotowanych programów rozwoju [Grochowski i in. 2012, s. 14]. W obliczu tak zdefiniowanych wspólnych problemów sektora kreatywnego jednym ze sposobów holistycznego podejścia do ich eliminacji jest współcześnie klastering, w tym koncepcja klastra kreatywnego.

\section{Potencjał rozwoju klastrów kreatywnych}

Pojęcie klastrów kreatywnych pojawiło się po raz pierwszy kilkanaście lat temu, jednak w literaturze przedmiotu wciąż brakuje jednoznacznej definicji tego typu klastrów. O takim stanie rzeczy decydują m.in.: niejednorodne definiowanie sektora kreatywnego, różnorodność partnerów klastrowych, skala i cel współpracy w ramach klastra, tworzenie nowej wartości, forma instytucjonalizacji klastrowej współpracy inicjowanej zarówno oddolnie, jak i odgórnie, która jest wspierana przez różnego rodzaju publiczne instrumenty (polityczne, prawne, finansowe). W ciągu kilkunastu ostatnich lat powstało wiele różnych definicji tego typu klastra, co wiązało się chociażby z intensywnym wykorzystaniem koncepcji klasteringu w polskim dyskursie publicznym i naukowym. W efekcie tego w teorii i praktyce gospodarczej klaster kreatywny najczęściej bywa rozumiany jako:

- grupa współpracujących organizacji i osób, wyłaniających się z lokalnych i regionalnych społeczności, sfery biznesu, nauki, kultury, sztuki, edukacji, zdrowia, rozrywki i wypoczynku [Knop, Macełko, Mendel 2011, s. 72]; 
- struktura zrzeszająca różnego rodzaju podmioty, przy czym najważniejszy jest w nich udział przedsiębiorstw kreatywnych, których główna wartość dla odbiorcy wynika $\mathrm{z}$ odniesienia do aspektów emocjonalnych i estetycznych [Olko 2015a, s. 115];

- struktura zrzeszająca współpracujące i konkurujące ze sobą podmioty funkcjonujące w trzech głównych obszarach sektora kreatywnego, takich jak: rdzeniowe dziedziny sztuki, przemysł kultury, przemysł i działalność kreatywna [Pięta-Kanurska 2013, s. 73];

- miejsce, które skupia kreatywne jednostki i organizacje podzielające zainteresowanie innowacyjnymi rozwiązaniami, mającymi zastosowanie w różnych sektorach gospodarki. Unikatowość, indywidualność i różnorodność partnerów klastrowych zapewnia synergiczność podejmowanych przez nich działań, co determinuje ostateczny poziom innowacyjności i konkurencyjności klastra [Ilczuk i in. 2011, s. 14];

- organizacja mniej lub bardziej sformalizowana, współtworzona przez współpracujące ze sobą podmioty gospodarcze, publiczne i społeczne, dostarczające dobra i usługi o określonej wartości kulturalnej i artystycznej, zaangażowane w działalność twórczą i kreujące produkty nasycone wiedzą [Główka, Jankowska 2012, s. 124];

- płaszczyzna, na której stykają się współpraca i konkurencja, kreatywność, kultura, ekonomia i technologia, która zorientowana jest na tworzenie i rozpowszechnianie kapitału intelektualnego oraz generowanie nowych miejsc pracy, z uwzględnieniem włączenia społecznego, różnorodności kulturowej i rozwoju człowieka [Newbigin 2010, s. 24].

Pogłębione badania nad rozwojem klastrów kreatywnych są prowadzone w Polsce od niedawna. Tym samym nie wypracowano jeszcze jednej, uniwersalnej definicji, adekwatnej do specyfiki polskich klastrów kreatywnych, w tym do specyfiki sektora kreatywnego.

Heterogeniczny charakter klastrów kreatywnych wynika z faktu, że mogą one skupiać na swoim terytorium podmioty, które zajmują się bardzo zróżnicowaną działalnością zarówno niekomercyjną (twórczość artystyczna i działalność kulturalna eksponująca realizację misji społecznej, autonomię twórczą i korzystająca z mecenatu publicznego), jak i komercyjną, a związaną np. z: projektowaniem, wzornictwem przemysłowym, promocją, komunikacją marketingową, aktywnością medialną, oprogramowaniem, aktywnością kulturalną, dotyczącą tworzenia i dostarczania wartości kultury dla odbiorców indywidualnych i masowych [Kotylak 2013a, s. 10; Olko 2014, s. 44]. Granice definicji klastra kreatywnego, jak również struktury klastra ciągle się zmieniają. Jednak bezsprzecznie pojęcie klastrów kreatywnych odnosi się do pojęcia kreatywności. To z kolei pojęcie oznacza: umiejętność tworzenia czegoś nowego na bazie łączenia wiedzy pozyskanej z różnych źródeł, rozwijanie lub wzbogacanie danego pomysłu o nowe elementy, czyniące go bardziej wartościowym, umiejętność tworzenia nowych idei lub postrzegania tych dotychczasowych 
w odmienny sposób, dzięki czemu możliwe jest nowe zastosowanie dotychczasowych idei [Grabowska 2013, s. 27]. Warto podkreślić, że pojęcie kreatywności nie jest zwykłą umiejętnością myślenia inaczej czy wytwarzania pomysłów, ale umiejętnością myślenia dywergencyjnego (rozbieżność, płynność i elastyczność myślenia, zdolność do redefiniowania pojęć, oryginalność) oraz zdolnością tolerowania istniejących sprzeczności i/lub poruszania się między pozornie sprzecznymi perspektywami [Kasza 2014, s. 51].

Koncepcja klastrów kreatywnych związana jest bezpośrednio z istnieniem skupisk firm i współpracujących z nimi różnorodnych organizacji, funkcjonujących w sektorze kreatywnym oraz w sektorach pokrewnych, szczególnie na obszarze dużych miast, w obrębie obszarów metropolitarnych. Nieco rzadziej klastry tego typu występują na poziomie subregionalnym, ograniczając się do sytuacji, gdy przestrzeń jest policentryczna, z wieloma współpracującymi ze sobą ośrodkami zgromadzonymi na stosunkowo małym obszarze [Stachowiak, Tomczak 2015, s. 76]. Skala ich działania i możliwości rozwoju determinowane są przede wszystkim przez takie czynniki, jak [Mikołajczyk, Kurczewska, Fila 2009, s. 126; Podogrodzka 2013, s. 110; Florida 2010, s. 338; Olko 2015a, s. 115]:

- kreatywni ludzie, przedsiębiorczy, zainteresowani nowościami i innowacjami, niekoniecznie $\mathrm{w}$ jednej dziedzinie, otwarci na zmiany;

- klasa kreatywna, klasa ludzi twórczych, wyróżniających się m.in. profesjonalizmem, wysokim poziomem wykształcenia, kreowaniem nowych kierunków w kulturze i sztuce, tolerancją i otwartością wobec innych członków społeczeństwa, inteligencją emocjonalną;

- otwarta przestrzeń jako katalizator pomysłów, talentów, relacji personalnych i organizacyjnych;

- środowisko i klimat twórczy stymulujące kreatywność jednostki i zespołów, oferujące różnorodność i nieograniczające wolności ekspresji twórczej;

- otwarta i elastyczna sieć relacji międzyludzkich, wzbogacająca indywidualność, czerpiąca energię od kreatywnych jednostek;

- wysoka koncentracja terytorialna podmiotów sektora kreatywnego;

- zakorzenienie i silne związanie z lokalnym środowiskiem kreatywnej społeczności i kultury, co pozwala na współtworzenie i wykorzystywanie tożsamości miejsca $i$ jego atrakcyjności.

Jednym z kluczowych czynników rozwoju klastra kreatywnego jest aktywność społeczeństwa obywatelskiego (w postaci zinstytucjonalizowanej) oraz pełnych inwencji liderów społecznych, których aktywność wykracza poza zwykle struktury instytucjonalne [Olko 2015b, s. 177]. Rozwój klastra kreatywnego wymaga także sprawnego partnerstwa kreatywnego. Ten typ partnerstwa zawierany jest głównie pomiędzy podmiotami sektora kultury i sektora kreatywnego. Celem tak budowanego partnerstwa kreatywnego, które może mieć charakter formalny i nieformalny, jest wytwarzanie innowacyjnych treści oraz transfer zdolności kreatywnych z kultury do innych dziedzin gospodarki i życia społecznego [Ilczuk i in. 2011, s. 8]. Do celów 
szczegółowych partnerstwa kreatywnego zaliczyć można np. [Ilczuk i in. 2011, s. 9; Lechwar 2013, s. 248]:

- pobudzanie wyobraźni i talentu w codziennym życiu w różnych organizacjach (publicznych, komercyjnych i społecznych),

- stymulowanie krzyżowania się wpływów pomiędzy sektorami gospodarki, dyscyplinami naukowymi itp.,

- wspieranie rozwoju kreatywnej ekonomii przez aktywne włączenie kreatywności opartej na kulturze do polityki innowacji,

- promowanie społecznych innowacji przez sztukę,

- ułatwienie dostępu do kultury i produktów kreatywnych,

- rozwój kapitału społecznego.

W opinii J. Markiewicz [2013, s. 64] kreatywne partnerstwa oparte na funkcjonowaniu klastrów powinny stanowić przestrzeń największej aktywności kreatywnej, w wymiarze zarówno ekonomicznym, technologicznym, kulturalnym, urbanistycznym, jak i społecznym. Efektem współpracy z artystami może być poprawa jakości produktów, rozwój koncepcji nowych produktów, zmiana modeli biznesowych, sprawne kształtowanie nowych trendów. Kreatywne partnerstwa zwiększają spójność społeczną, integrując ludzi wokół wspólnych problemów, wyzwalając w nich postawę solidarności, tak by minimalizować negatywne skutki problemów społeczno-gospodarczych [Policy handbook... 2014, s. 8-9].

W klastrach kreatywnych zakotwiczony jest bardzo duży potencjał rozwoju. Z badań wynika, że podmioty sektora kreatywnego współtworzą w coraz większym stopniu PKB oraz kreują wciąż nowe miejsca pracy oraz tzw. przemysły wschodzące (emerging industries), wzmacniając lokalne i globalne łańcuchy wartości [Kotylak 2013a, s. 13; Szultka 2012, s. 8]. Nowe branże kreowane są m.in. przez innowacje technologiczne i inne radykalne innowacje (disruptive innovations). Potencjał rozwoju klastrów kreatywnych ma strategiczne znaczenie dla sprawnego funkcjonowania gospodarki lokalnej, społeczeństwa oraz indywidualnych podmiotów gospodarczych, szczególnie tych mikro, małych i średnich. W dokumencie strategicznym Komisji Europejskiej z 2010 roku, dotyczącym uwalniania potencjału przedsiębiorstw z branży kultury i branży twórczej, wskazano, że przedsiębiorstwa te dysponują wielkim niewykorzystanym potencjałem tworzenia wzrostu gospodarczego i miejsc pracy. Ponadto mają rzeczywisty potencjał pozwalający na sprawną realizację celów strategii Europa 2020, w tym jej kluczowych inicjatyw, takich jak unia innowacji, agenda cyfrowa, przeciwdziałanie zmianom klimatu, program na rzecz nowych umiejętności i zatrudnienia oraz polityka przemysłowa w erze globalizacji [Koszarek 2012, s. 3; European Commission 2010, s. 2-15].

Klastry kreatywne o wysokim poziomie konkurencyjności, dzięki procesom „rozlewania się”, mogą dostarczać swym interesariuszom w otoczeniu wewnętrznym i zewnętrznym licznych korzyści, na przykład o charakterze ekonomicznym, społecznym i kulturalnym (tab. 1). Korzyści te wynikają z przestrzennej bliskości partnerów, ukształtowanego kapitału społecznego, wspólnych zasobów material- 
nych i niematerialnych, koopetycji, która eliminuje np. zagrożenie stagnacji technologicznej. W opinii M. Koszarek [2012, s. 7] klastry kreatywne mogą podejmować działania zarówno w kierunku zapewnienia sprzyjających warunków działania dla kreatywnych pracowników, jak i w kierunku bezpośredniego stymulowania rozwoju kreatywnych firm. Nie bez znaczenia jest również fakt, że w klastrach tych powstają nowe modele biznesowe i technologie, które przyczyniają się do rozwoju społeczeństwa informacyjnego i cyfrowego.

Warto podkreślić, że firmy kreatywne są bardzo aktywne w poszukiwaniu właściwej lokalizacji, najbardziej sprzyjającej ich działalności. Przekłada się to na ich mobilność przestrzenną i wędrówkę do miejsc i regionów, gdzie szanse na dynamiczny rozwój są jak największe [Grochowski i in. 2012, s. 31]. Lokalizacja firm kreatywnych na obszarze aktywności klastra kreatywnego nie jest przypadkowa. Jest ona wynikiem racjonalnych decyzji właścicieli tych firm, którzy traktują klaster jako przestrzeń atrakcyjną dla dalszego wzrostu i rozwoju. Klastry kreatywne w wielu przypadkach skupiają w swych strukturach znacznie więcej innowacyjnych

Tabela 1. Wybrane przykłady korzyści, które wynikają z rozwoju klastrów kreatywnych

\begin{tabular}{|c|c|c|}
\hline Kor & $\mathrm{Ko}$ & Ko \\
\hline $\begin{aligned} & \text { - } \text { tworzenie nowych źródeł } \\
& \text { dochodów } \\
& \text { - rozwój aglomeracji miejskiej } \\
& \text { - nowe inwestycje strategiczne } \\
& \text { - wzrost konkurencyjności } \\
& \text { gospodarki regionu } \\
& \text { - poprawa konkurencyjności } \\
& \text { organizacji klastrowych } \\
& \text { - spadek bezrobocia } \\
& \text { - aktywne przeciwdziałanie } \\
& \text { bezrobociu } \\
& \text { - zmniejszenie fluktuacji } \\
& \text { wartościowej grupy } \\
& \text { pracowników wiedzy } \\
& \text { - stymulowanie rozwoju innych } \\
& \text { branż w gospodarce } \\
& \text { - rozwój przedsiębiorczości } \\
& \text { lokalnej } \\
& \text { - atrakcyjność określonych } \\
& \text { lokalizacji } \\
& \text { - rozwój start-upów } \\
& \text { - redukcja kosztów } \\
& \text { transakcyjnych i ryzyka }\end{aligned}$ & $\begin{aligned} & \text { - wspieranie kulturowej } \text { różnorodności } \\
& \text { - integracja i spójność społeczna } \\
& \text { - włączenie społeczne grup } \\
& \text { wykluczonych } \\
& \text { - rozwój kreatywności } \\
& \text { i umiejętności w zakresie } \\
& \text { innowacji } \\
& \text { - holistyczny rozwój człowieka } \\
& \text { - kreowanie przestrzeni } \\
& \text { promującej rozwój osobisty } \\
& \text { i samorealizację } \\
& \text { - zachowanie równowagi } \\
& \text { pomiędzy przestrzenią } \\
& \text { prywatną a zawodową } \\
& \text { - wzrost świadomości } \\
& \text { w zakresie obywatelskiej } \\
& \text { i demokratycznej partycypacji } \\
& \text { - nowe formy edukacji } \\
& \text { - sprawne zaspokajanie potrzeb } \\
& \text { społecznych } \\
& \text { - pielęgnacja wartości } \\
& \text { społeczeństwa obywatelskiego }\end{aligned}$ & $\begin{array}{l}\text { - wzrost atrakcyjności oferty } \\
\text { kulturalnej } \\
\text { - pomoc artystom } \\
\text { w docieraniu do szerszej } \\
\text { publiczności } \\
\text { - promowanie talentów } \\
\text { i rozwój osobowy } \\
\text { - zwiększanie zrozumienia, } \\
\text { świadomości, empatii } \\
\text { i szacunku wobec innych } \\
\text { kultur } \\
\text { - rozwój atrakcyjnej } \\
\text { infrastruktury kulturalnej } \\
\text { - sprawny transfer wiedzy } \\
\text { - promocja tradycji kultury } \\
\text { - międzynarodowe sieci } \\
\text { współpracy kulturalnej } \\
\text { - wzmocnienie i integracja } \\
\text { sektora kreatywnego, } \\
\text { w tym kultury } \\
\text { - kreowanie marki } \\
\text { kulturalnej regionu } \\
\text { - równowaga między } \\
\text { tradycją a innowacją }\end{array}$ \\
\hline
\end{tabular}

Źródło: opracowanie na podstawie: [Grabowska 2013, s. 28-29; Stachowiak, Tomczak 2015, s. 68-70; Grochowski i in. 2012, s. 5]. 
firm niż w pozostałych sektorach gospodarki, przez co są one bardziej innowacyjne od innych klastrów przemysłowych. Wiele firm z sektorów kreatywnych wchodzi w bezpośrednią interakcję z klientami, odgrywając coraz większą rolę w kreowaniu innowacji i przyspieszaniu wzrostu innych gałęzi gospodarki [Newbigin 2010, s. 20]. Tym samym klastry kreatywne uznaje się współcześnie za wartościową otwartą formę działania, płaszczyznę wymiany wiedzy i doświadczeń, tworzenia i komercjalizacji innowacyjnych pomysłów, kształtowania innowacyjnej infrastruktury dzięki partnerskiej współpracy.

Jednak by klaster był zdolny do ciągłego generowania tego typu korzyści, niezbędne jest $\mathrm{m}$.in. profesjonalne zarządzanie klastrem, w tym sprawne niwelowanie negatywnego oddziaływania różnych barier rozwoju. S. Olko [2015b, s. 182] na podstawie własnych badań wskazuje, że w polskich klastrach kreatywnych głównymi barierami rozwoju są bariery mentalne, w tym brak zaufania oraz - szczególnie nasilone w środowisku projektowania i sztuki - poczucie własnej wartości i oczekiwanie szacunku. Pokonanie tych barier jest istotnym wyzwaniem dla menedżerów klastrów. Wymaga ono od nich odpowiednich kompetencji ekonomicznych, administracyjnych oraz społecznych.

Zarządzanie klastrem kreatywnym jest procesem niezwykle złożonym i problematycznym, zważywszy na dużą różnorodność członków tego typu klastra. Tym bardziej przydatne mogą być opracowane standardy zarządzania klastrem oraz dobre praktyki innych klastrów w tym zakresie. Na przykład w trakcie realizacji projektu regioNet w ramach inicjatywy SMART+, skoncentrowanego na transferze dobrych praktyk w zakresie skuteczności zarządzania klastrami w Polsce, Niemczech i Rumunii, zidentyfikowano kluczowe wytyczne dla menedżerów klastrów, zgodnie z którymi nie należy [Espig i in. 2013, s. 50]:

- przerywać pracy z entuzjazmem na rzecz rozwoju klastra,

- utrzymywać ukrytych planów w ramach klastra,

- przejawiać stronniczości w stosunku do członków klastra,

- zapraszać do sieci współpracy tych firm, które walczą o przetrwanie, a koncentrować się wokół potencjalnych partnerów innowacyjnych,

- tracić orientacji strategicznej w zarządzaniu wieloma różnymi projektami współpracy w ramach klastra, realizowanymi w tym samym czasie,

- lekceważyć wysiłków innych i aktualnego poziomu konkurencyjności klastra w otoczeniu,

- zapominać o promocji wyników klastra,

- wdrażać zbyt odważnych kampanii promocyjnych idei klastra, które mogłyby w pewnym stopniu zaszkodzić relacjom z kluczowymi interesariuszami,

- zapominać o tym, że zawsze warto organizować spotkania integracyjne członków klastra (w różnej formie i charakterze).

Znaczenie i rolę klastrów kreatywnych najlepiej jest zilustrować za pomocą konkretnych przykładów ich aktywności. W Polsce funkcjonuje kilkanaście tego typu struktur klastrowych np.: Śląski Klaster Dizajnu, Zachodniopomorski Klaster Prze- 
mysłów Kreatywnych, Klaster Poligraficzno-Reklamowy w Lesznie. W grupie tej dominują ilościowo klastry informatyczne (ICT). Warto podkreślić, że wśród 16 Krajowych Klastrów Kluczowych (KKK), wybranych w procedurze konkursowej Ministerstwa Rozwoju, 3 klastry informatyczne reprezentują grupę klastrów kreatywnych [http://www.pi.gov.pl].

Śląski Klaster Dizajnu tworzą indywidualni projektanci, innowacyjne firmy, instytuty badawcze, organizacje pozarządowe i uczelnie wyższe z województwa śląskiego. Aktywność członków klastra koncentruje się na współpracy w zakresie opracowywania i wdrażania nowych produktów i usług, projektowania przestrzeni publicznej, promocji i rewitalizacji przestrzeni, projektowania architektury, mebli miejskich, systemów informacji i usług publicznych. Ponadto kompetencje klastra dotyczą projektowania maszyn i urządzeń, materiałów, pojazdów, a także wzornictwa przemysłowego, brandingu i projektowania tożsamości wizualnej. Główne cele strategiczne klastra zakładają wspieranie powstawania nowych innowacyjnych produktów i firm w regionie, rozwój współpracy partnerskiej na rzecz innowacji, transfer wiedzy, technologii i innowacji pomiędzy członkami klastra. Poprzez wykorzystanie potencjału wiedzy i innowacji, jakim cechuje się design, klaster zamierza wzmocnić konkurencyjność gospodarki regionu [http://klasterdizajnu.pl].

Zachodniopomorski Klaster Przemysłów Kreatywnych zakorzeniony w Szczecinie tworzy 60 podmiotów, zajmujących się reklamą, multimediami, grafiką, filmem, Internetem, projektowaniem, sztuką, kulturą i branżami pokrewnymi. Misja klastra zakłada aktywne wspieranie podmiotów kreatywnych zrzeszonych w klastrze w zakresie aktywności innowacyjnej, usprawnień organizacyjnych, rozwoju współpracy biznesowej. Klaster ma sformułowanych kilka celów strategicznych, takich jak np.: przyciąganie klasy kreatywnej, kreowanie wizerunku regionu jako zagłębia branż kreatywnych, promocja innowacyjnych rozwiązań w przemysłach kreatywnych, wspieranie umiędzynarodowienia członków klastra, integracja przedsiębiorców kreatywnych. Jedną z lokalnych inicjatyw realizowanych w klastrze są Targi Przemysłów Kreatywnych. Wizja klastra zakłada, że do 2020 roku będzie go współtworzyła silna grupa podmiotów kreatywnych [https://klaster.biz].

Klaster Poligraficzno-Reklamowy w Lesznie funkcjonuje jako zinstytucjonalizowany podmiot od 2007 roku i zrzesza głównie lokalne podmioty z branży poligraficznej i reklamowej. Jego głównymi celami są m.in.: rozwój platformy wymiany informacji o nowych technologiach stosowanych w branży klastra, rozwój kwalifikacji pracowników branży, dostosowanie oferty edukacyjnej do potrzeb rynku pracy klastra, rozwój innowacji organizacyjnych i technologicznych. Inicjatywa klastrowa powstała na fundamencie lokalnych tradycji poligraficznych, m.in. dla obrony rynku lokalnego przed ekspansją silnych sąsiadujących ośrodków przemysłowych - takich jak: Poznań i Wrocław. Spotkania integracyjne i robocze członków klastra organizowane są systematycznie w ich siedzibach, by móc bliżej zapoznać się z ich aktywnością [http://www.poligrafia.leszno.eu]. Większość członków klastra jest zadowolona 
Krystyna Moszkowicz, Bogusław Bembenek

ze współpracy w klastrze, gdyż tworzy on środowisko pozytywnie wpływające na ich innowacyjność i konkurencyjność. W ich opinii także współpraca z konkurentami w klastrze jest dla nich korzystna [Jankowska 2012, s. 291].

\section{Wartość otwartych innowacji dla konkurencyjności klastrów kreatywnych}

Podmioty komercyjne, publiczne i społeczne, współtworzące klastry kreatywne na bazie koopetycji, niejednokrotnie stają w obliczu aktualnego problemu - w jaki sposób tworzyć lepsze rozwiązania doskonalące jakość własnej oferty, jak zwiększyć ostateczną użyteczność i funkcjonalność produktów kreatywnych, jak pełniej dostosować ofertę tych produktów do potrzeb indywidualnego klienta? Nie bez znaczenia jest także fakt, że ilościowo w tego typu klastrach dominują firmy z sektora MŚP, które wykazują względnie niską aktywność w prowadzeniu własnej działalności $\mathrm{B}+\mathrm{R}$ ze względu na brak odpowiednich w tym celu zasobów (m.in. ludzkich i finansowych). Tym samym te i inne problemy mogą stymulować decyzje o wspólnym tworzeniu innowacyjnych rozwiązań zgodnie z ideą otwartych innowacji.

W literaturze przedmiotu koncepcje teoretyczne otwartych innowacji i klastrów zawierają wiele komplementarnych pojęć i atrybutów [Juchniewicz 2014, s. 114]. Wynika to m.in. z faktu, że współczesny paradygmat otwartych innowacji podkreśla [Inauen, Schenker-Wicki 2011, s. 497; Huang, Rice 2013, s. 88-89]:

- systematyczne identyfikowanie, badanie i wykorzystywanie różnych źródeł okazji do tworzenia innowacji, które mają potencjał komercyjny,

- integrowanie wybranych źródeł okazji z potencjałem zasobowym,

- stosowanie różnych sposobów rozwijania i wykorzystywania zidentyfikowanych okazji.

Koncepcja otwartych innowacji wskazuje na potrzebę kompleksowego (holistycznego) podejścia do zarządzania innowacjami, gdyż o wartości innowacji mogą decydować zarówno wewnętrzne zasoby potencjału kreatywnego, jak i zewnętrzne - znajdujące się w posiadaniu kluczowych interesariuszy zewnętrznych. W koncepcji tej rola interesariuszy zewnętrznych ujawnia się na etapie zarówno tworzenia i oceny pomysłów, jak i późniejszego przekształcania ich w innowacyjne rozwiązania, późniejszej komercjalizacji oraz dyfuzji w otoczeniu [Rojek 2014, s. 211]. Otwarte podejście do innowacji włącza jako uczestników procesu innowacyjnego także osoby, które używają produktu, mają głęboką wiedzę na jego temat i mogą dzięki swoim uwagom, spostrzeżeniom, propozycjom wnieść określoną wartość w jego doskonalenie lub tworzenie całkiem nowego produktu [Malinowski 2015, s. 47]. Wykorzystanie zasobów wiedzy i kreatywności zewnętrznych partnerów w procesie innowacyjnym dyktowane jest chęcią stworzenia rozwiązań oryginalnych, adekwatnych do istniejących i przyszłych potrzeb konsumentów, chęcią redukcji potencjalnych kosztów i ryzyka prowadzonej działalności B+R. Otwarty model innowacji nie tylko stwarza możliwość pozyskiwania wiedzy z zewnątrz do 
danej organizacji, ale również wskazuje na szansę wykorzystania jej poza organizacją. W wielu przypadkach część zasobów wiedzy jest w danej chwili w danej organizacji jedynie magazynowana i niewykorzystywana, podczas gdy dla innej organizacji ta sama wiedza może być bardzo użyteczna, może być podstawą dalszego rozwoju wiedzy i innowacji o różnym charakterze. Organizacja, udostępniając własne zasoby wiedzy swym partnerom klastrowym, np. w formie patentów i licencji, a szczególnie te o małym znaczeniu strategicznym dla własnego biznesu, może mieć z tego tytułu wiele wymiernych korzyści [Przybylska 2015, s. 210]. Oczywiście w zależności od tego, co dla danej organizacji będzie korzystne, w jednym przypadku wartościowszy może być system licencjonowania, w innych - bezpłatne dzielenie się wiedzą (free revealing). W tym drugim przypadku ma miejsce wolny dostęp do bezpłatnego ujawniania zainteresowanym podmiotom zastrzeżonych informacji o wynalazku uzyskanym dzięki wspólnym nakładom osób lub organizacji, przez co informacje te stają się dobrem publicznym [Janasz, Janasz 2015, s. 372]. W klastrach kreatywnych niekiedy komercjalizacja wspólnego projektu innowacyjnego, będącego wynikiem zbiorowego wysiłku intelektualnego, sama w sobie ma na tyle wysoką użyteczność, że nie wymaga już typowej ochrony instytucjonalnej, która w tym przypadku mogłaby stanowić barierę w dalszym doskonaleniu tego projektu. Sytuacja ta, wpisując się w istotę otwartej innowacji, spójna jest jednocześnie z koncepcją free revealing [Niklewicz-Pijaczyńska 2013, s. 348; Hippel, Krogh 2006, s. 295-298].

W modelu otwartych innowacji organizacja może rozwijać i wdrażać zarówno własne pomysły, jak i te zgłoszone przez interesariuszy zewnętrznych. Elastyczna współpraca w tym zakresie na różnych etapach procesu innowacji powoduje, że granice między organizacją a jej otoczeniem są wyraźnie rozmyte [Sopińska, Mierzejewska 2016, s. 436]. Oczywiście otwarte innowacje nie tylko nie zmniejszają roli własnych prac $\mathrm{B}+\mathrm{R}$ w procesie innowacyjnym, ale stymulują je, pracowników wiedzy zaś angażują w roli brokerów wiedzy do budowy sieci zewnętrznych powiązań [Krupski 2014, s. 11]. W ten sposób w strukturach klastrowych mogą pojawić się efekty synergiczne wzrostu innowacyjności, które są ściśle powiązane z efektywnością współpracy ich członków podczas tworzenia i wykorzystywania wiedzy [Dolińska 2012, s. 203; Huggins 2008, s. 277-279, 285].

Otwarte innowacje w klastrach kreatywnych okazały się już bardzo wartościowym rozwiązaniem w przypadku produkcji np. gier komputerowych. Firmy produkujące tego typu produkty kreatywne najpierw zapraszają graczy do bezpłatnego ich testowania, po czym klienci (aktywni gracze) przekazują poprzez platformy crowdsourcingowe wszelkie swoje uwagi, spostrzeżenia o błędach i niedoskonałościach produktu. W ten sposób jako prosumenci partycypują w tworzeniu nowych wersji gier, często bardziej innowacyjnych produktów. W wielu przypadkach tak powstałe produkty kreatywne stają się elementem innowacyjnych produktów czy usług wytwarzanych w innych firmach, innych branżach (np. innowacje imitacyjne). Sukces danego produktu kreatywnego może nie tylko wpłynąć pozytywnie na rozwój bran- 
ży macierzystej, ale także być solidną podstawą rozwoju nowych branż [Szultka 2012, s. 60].

W obliczu turbulentnego otoczenia sprawne zarządzanie rozwojem klastra kreatywnego wymaga implementacji założeń modelu otwartej innowacji. Proces wdrożeniowy w tym zakresie może przebiegać dwubiegunowo, na poziomie zarówno makro, jak i mikro, tj.:

- na poziomie klastra i organizacji klastrowej (koordynatora klastra) w zakresie tworzenia np. innowacji organizacyjnych, które usprawniają zarządzanie rozwojem klastra, czy innowacji marketingowych i produktowych - w przypadku wspólnej oferty produktowej klastra,

- na poziomie autonomicznych organizacji członków klastra.

Poprawna implementacja tego modelu procesu innowacyjnego na poziomie makro i/lub mikro klastra sprzyjać może bardziej efektywnemu wykorzystaniu posiadanych zasobów wewnętrznych, jak również pozyskiwaniu niezbędnych zasobów z bliższego i dalszego otoczenia. Z punktu widzenia tworzenia dogodnych warunków do rozwoju otwartych innowacji w klastrze menedżerowie klastrów kreatywnych powinni podejmować takie działania, jak np. [Frączek 2012, s. 32-34; Grochowski i in. 2012, s. 80; Szultka 2012, s. 54; Naumienko 2014, s. 108]:

- współtworzyć wraz z innymi kluczowymi interesariuszami klastra twórczą i inspirującą kulturę innowacji, twórcze środowisko pracy,

- uświadamiać, jaką wartość mogą generować otwarte innowacje, pomimo istniejących barier transferu wiedzy,

- zapewnić pomoc swoim członkom, szczególnie tym z sektora MŚP, w zapoznaniu się z najnowszymi technologiami, modelami/strategiami biznesowymi stosowanymi na świecie,

- rozwijać w klastrze komplementarne kompetencje, których nie oferują podmioty działające w klastrze, m.in. poprzez inspirowanie współpracy z innymi organizacjami z innych sektorów czy też klastrów, funkcjonujących w kraju i za granicą,

- identyfikować nowe specyficzne umiejętności i kompetencje potrzebne w ramach realizacji wspólnych innowacyjnych projektów i przedsięwzięć biznesowych oraz rozwijać je systematycznie w klastrze poprzez odpowiednie, specjalistyczne programy szkoleniowe przeznaczone dla członków klastra,

- identyfikować trendy rynkowe oraz wspierać procesy redefiniowania i unowocześniania istniejących profili aktywności klastra i podmiotów klastrowych w kierunku nowych, strategicznych specjalizacji, uwzględniających np. powiązania pomiędzy branżami,

- tworzyć wciąż nowe rozwiązania sprzyjające współpracy w obszarze innowacji, typu otwarte wirtualne platformy współpracy i wymiany pomysłów wzbogacone o aplikacje testujące, wirtualne fabryki prototypów itp.,

- zapewnić pomoc w uruchomieniu linii kredytowych odpowiadających konkretnym potrzebom inwestycyjnym firmom z sektora MŚP, 
- zapewnić pomoc w sieciowaniu firm w ramach sektora klastra i sektorów pokrewnych na rynku krajowym i rynkach zagranicznych,

- budować wspólnie z partnerami klastrowymi bazę wiedzy o sektorze kreatywnym (pozycja klastra na rynku produktów kreatywnych, jakość i poziom konkurencji w kraju i za granicą, nisze rynkowe, obszary rynku o większym potencjale rozwojowym itp.) i ułatwić członkom klastra korzystanie z tej bazy przy użyciu narzędzi ICT,

- współtworzyć wraz z innymi interesariuszami korzystne warunki rozwoju klastra, gdzie aktywność kreatywna jego członków będzie wywierać większy wpływ na lokalne otoczenie.

Oczywiście wskazane rekomendacje nie wyczerpują listy działań, jakie powinny być podejmowane w klastrze, celem tworzenia odpowiedniego klimatu sprzyjającego rozwojowi otwartych innowacji. Na przykład bardzo ważne są wspólne dyskusje w klastrze dotyczące ochrony praw własności intelektualnej i przemysłowej. Konieczne jest bowiem ustalenie, w jaki sposób można rozporządzać dobrami własności intelektualnej w ramach klastra tak, aby było to jak najbardziej efektywne, skuteczne i jednocześnie zgodne z prawem [Perkowski, Rynkiewicz 2011, s. 12]. Jest to kolejne istotne wyzwanie w zarządzaniu klastrem, gdyż w zależności od charakteru branżowego klastra i wspólnej działalności innowacyjnej członków klastra różne są wymagania w zakresie ochrony własności intelektualnej.

\section{Zakończenie}

Natura klastrów kreatywnych wciąż nie jest jeszcze w pełni rozpoznana. Różnorodność definicji klastrów kreatywnych, w tym szeroki wachlarz partnerów współtworzących tego typu struktury, sprawiają, że dużym wyzwaniem jest precyzyjne ich badanie i porównywanie w skali krajowej oraz międzynarodowej. Niemniej jednak znaczenie ich potencjału dla rozwoju gospodarczego już od kilkunastu lat mocno podkreślają instytucje publiczne i rządowe, $\mathrm{w}$ tym instytucje europejskie i agendy Unii Europejskiej.

Klastry kreatywne, które oparte są na wielokierunkowych interakcjach biznesowych i społecznych, zachodzących na danym terytorium i angażujących różnorodnych partnerów, generują coraz większą wartość dla rozwoju gospodarki opartej na wiedzy. W potencjale tych klastrów upatruje się szansy na minimalizowanie istniejącej luki technologicznej, która wyraża różnicę poziomu potencjałów technologicznych rodzimej gospodarki w porównaniu z krajami najbardziej innowacyjnymi. Jednak by struktury te $\mathrm{w}$ optymalnym wymiarze mogły czerpać korzyści z efektu klastrowej synergii, niezbędne okazuje się coraz większe otwarcie partnerów klastrów na współpracę i współtworzenie innowacji w modelu otwartych innowacji.

Otwarte innowacje stanowią wciąż nowe wyzwanie w zarządzaniu klastrami kreatywnymi. Jednocześnie, uwzględniając charakter tych klastrów, takie otwarte podejście do tworzenia nowych i wartościowych rozwiązań w klastrach wydaje się 
właściwym kierunkiem ich rozwoju. Swobodna wymiana wiedzy między partnerami, bazująca na wzajemnym zaufaniu, pozwala dynamizować sieć relacji w klastrach i wzmacniać zaangażowanie tych partnerów na rzecz wspólnego zrównoważonego rozwoju. Może przyczyniać się do tworzenia nowych produktów i usług kreatywnych celem budowania unikatowej i trudnej do imitacji kombinacji indywidualnych i wspólnych zasobów strategicznych, umożliwiających uzyskanie względnie trwałej przewagi konkurencyjnej w skali krajowej i międzynarodowej.

\section{Literatura}

Bagwell S., 2008, Creative clusters and city growth, Creative Industries Journal, vol. 1, nr 1, s. 31-46. Dolińska M., 2012, Uwarunkowania organizacyjne, marketingowe i rynkowe działalności innowacyjnej przedsiębiorstw, Roczniki Ekonomii i Zarządzania, tom 4 (40), s. 201-213.

Dudek-Mańkowska S., Fuhrmann M., Grochowski M., Zegar T., 2012, Sektor kreatywny a przestrzenie publiczne w Warszawie, Mazowsze. Studia Regionalne, nr 11, s. 147-157.

Espig T., Lehman J., Jakubowska-Łazęcka J., Obara E., Suta I., Gergely T., Suteu A., Farcau D., 2013, Tworzenie i zarządzanie klastrami oraz sieciami wspótpracy. Podręcznik dobrych praktyk, MARR, Kraków.

European Commission, 2010, Green paper: unlocking the potential of cultural and creative industries, European Commission, Brussels.

Florida R., 2010, Narodziny klasy kreatywnej, Narodowe Centrum Kultury, Warszawa.

Frączek D., 2012, Using Clusters to Address Emerging Industries and Services, TACTICS, Warszawa.

Główka C., Jankowska B., 2012, Koncepcja kreatywnej bezdomności i jej rola w rozwoju klastra kreatywnego - przypadek Klastra Poligraficzno-Reklamowego w Lesznie, [w:] Klastry - wiedza, innowacyjność, rozwój, red. J. Buko, M. Frankowska, Zeszyty Naukowe Uniwersytetu Szczecińskiego, nr 719, Ekonomiczne Problemy Usług, nr 94, Szczecin.

Grabowska A., 2013, Przemyst kreatywny a nowe paradygmaty rozwoju Szczecińskiego Obszaru Metropolitalnego, [w:] Kultura, kreatywność i biznes - wyzwania dla polityki regionalnej, red. K. Janasz, S. Bąkowska, J. Markiewicz, M. Tomczyk, Zeszyty Naukowe Uniwersytetu Szczecińskiego, nr 793, Ekonomiczne Problemy Usług, nr 107, Szczecin.

Grochowski M., 2010, Sektor kreatywny w Warszawie. Potencjat $i$ warunki rozwoju, Narodowe Centrum Kultury, Warszawa.

Grochowski M., Dudek-Mańkowska S., Fuhrmann M., Zegar T., 2012, Sektor kreatywny w województwach pomorskim i kujawsko-pomorskim. Raport z badań, Agencja Rozwoju Pomorza, Gdańsk.

Hippel E., Krogh G., 2006, Free revealing and the private-collective model for innovation incentives, R\&D Management, vol. 36, nr 3, s. 295-306.

Huang F., Rice J., 2013, Does open innovation work better in regional clusters?, Australasian Journal of Regional Studies, vol. 19, no. 1, s. 85-120.

Huggins R., 2008, The evolution of knowledge clusters, Economic Development Quarterly, vol. 22, nr 4, s. 277-289.

Ilczuk D., Krzysztofek K., Bender E., Nowak M., Wójcik A., 2011, Partnerstwa kreatywne w Polsce. Raport końcowy z badania, Fundacja Pro Cultura, Warszawa.

Inauen M., Schenker-Wicki A., 2011, The impact of outside - in open innovation on innovation performance, European Journal of Innovation Management, nr 14(4), s. 496-520.

Janasz W., Janasz K., 2015, Determinanty innowacyjności współczesnej i inteligentnej organizacji, Zeszyty Naukowe Uniwersytetu Szczecińskiego, nr 855, Finanse, Rynki Finansowe, Ubezpieczenia, nr 74, tom 1, Szczecin. 
Jankowska B., 2012, Koopetycja w klastrach kreatywnych, Wydawnictwo Uniwersytetu Ekonomicznego w Poznaniu, Poznań.

Juchniewicz M., 2014, Model otwartych innowacji w przemyśle spożywczym: skala i znaczenie zjawiska, Zagadnienia Ekonomiki Rolnej, nr 3, s. 107-118.

Kasza J., 2014, Wieczna radość czy przymus kreatywności - próba spojrzenia na retorykę kreatywności z punktu widzenia kulturowej ekonomii politycznej, [w:] Kreatywność i innowacyjność w erze cyfrowej. Twórcza destrukcja 2, red. A. Zorska, M. Molęda-Zdziech, B. Jung, Oficyna Wydawnicza Szkoły Głównej Handlowej w Warszawie, Warszawa.

Knop L., Macełko M., Mendel I., 2011, Klastry kreatywne we współczesnych polskich realiach, Organizacja i Zarządzanie, nr 4 (16), Wyd. Politechniki Śląskiej, s. 63-80.

Koszarek M., 2012, Diagnoza sektora branż kreatywnych na obszarze Metropolii Gdańskiej, Gdańska Fundacja Przedsiębiorczości, Gdańsk.

Kotylak S., 2013a, Przemyst kreatywny - nowa era twórczej równowagi, [w:] Przemyst kreatywny: ekonomia na styku kultury i biznesu, red. J. Stankiewicz, Z. Binek, S. Kotylak, Wyd. MAjUS, Zielona Góra.

Kotylak S., 2013b, Znaczenie sektora kreatywnego w polityce regionu, [w:] Kultura, kreatywność i biznes - wyzwania dla polityki regionalnej, red. K. Janasz, S. Bąkowska, J. Markiewicz, M. Tomczyk, Zeszyty Naukowe Uniwersytetu Szczecińskiego nr 793, Ekonomiczne Problemy Usług, nr 107, Szczecin.

Krupski R., 2014, Innowacje wartości i innowacje otwarte w kontekstach odpowiednich dla nich strategii, [w:] Kreatywność, innowacyjność, przedsiębiorczość. Zarzadzanie operacyjne w teorii i praktyce organizacji biznesowych, publicznych i pozarzadowych, red. L. Kowalczyk, F. Mroczko, Prace Naukowe Wałbrzyskiej Wyższej Szkoły Zarządzania i Przedsiębiorczości, tom 30(5), Wałbrzych.

Lechwar M., 2013, Kreatywne partnerstwa szansq na ograniczenie problemów obszarów peryferyjnych - studium przypadku, Nierówności Społeczne a Wzrost Gospodarczy, nr 34, s. 247-254.

Malinowski B., 2015, Wykorzystanie crowdsourcingu i otwartej innowacji na przyktadzie platformy internetowej My Starbucks Idea, [w:] Wybrane problemy zarzadzania i finansów. Studia przypadków, red. W. Grzegorczyk, Wyd. Uniwersytetu Łódzkiego, Łódź.

Markiewicz J., 2013, Kreatywne partnerstwa w kontekście rozwoju przemystów kreatywnych w Szczecinie, [w:] Kultura, kreatywność i biznes - wyzwania dla polityki regionalnej, red. K. Janasz, S. Bąkowska, J. Markiewicz, M. Tomczyk, Zeszyty Naukowe Uniwersytetu Szczecińskiego, nr 793, Ekonomiczne Problemy Usług, nr 107, Szczecin.

Mikołajczyk B., Kurczewska A., Fila J., 2009, Klastry na świecie. Studia przypadków, Difin, Warszawa.

Naumienko P.F., 2014, Rola koordynatora, animatora klastra jako element budowy przewagi konkurencyjnej sektora MSP, Studia Ekonomiczne Regionu Łódzkiego, nr XIII, s. 105-114.

Newbigin J., 2010, Kreatywna gospodarka: przewodnik dla poczatkujących, British Council, Londyn.

Niklewicz-Pijaczyńska M., 2013, Innowacje przełomowe w modelu open innovation i ekonomii free revealing, Zarządzanie i Finanse, tom 11, nr 4/3, s. 335-351.

Obłąkowska-Kubiak K., 2014, Sektor kultury i kreatywny jako wyzwanie dla matych i średnich przedsiębiorstw w Polsce, Studia Ekonomiczne Regionu Łódzkiego, nr XIII, s. 33-45.

Olko S., 2014, Badanie kompetencji w sieciach i klastrach $w$ przemysłach kreatywnych, Zeszyty Naukowe Politechniki Śląskiej, Organizacja i Zarządzanie, nr 76, Gliwice.

Olko S., 2015a, Instrumenty wsparcia klastrów kreatywnych w Polsce i Europie, Barometr Regionalny, tom, 13 , nr 4, s. 113-118.

Olko S., 2015b, Rola klastrów w przemysłach kreatywnych w rozwoju miast, [w:] Gospodarka lokalna w teorii i praktyce, red. R. Brol, A. Raszkowski, A. Sztando, Prace Naukowe Uniwersytetu Ekonomicznego we Wrocławiu, nr 391, Wrocław.

Perkowski M., Rynkiewicz S., 2011, Innowacje w klastrach. Jak chronić własność intelektualną?, PARP, Warszawa. 
Pięta-Kanurska M., 2013, Znaczenie sektora kreatywnego w rozwoju miast i regionów, Acta Universitatis Lodziensis, Folia Oeconomica, nr 290, s. 71-82.

Podogrodzka M., 2013, Klasa kreatywna a rozwój gospodarczy regionu w Polsce, Ekonomia, nr 3 (24), Wyd. Uniwersytetu Ekonomicznego we Wrocławiu, Wrocław, s. 106-118.

Przybylska N., 2015, Rozwój innowacyjności przedsiębiorstw i regionu poprzez otwarte innowacje, [w:] Rola zarzadzania projektami i procesami w budowaniu przewagi konkurencyjnej $w$ wymiarze lokalnym i regionalnym, red. E. Stroińska, Społeczna Akademia Nauk, Łódź.

Rojek D., 2014, Otwarte innowacje jako model interaktywnego zarzadzania innowacjami, Zeszyty Naukowe Uniwersytetu Przyrodniczo-Humanistycznego w Siedlcach, seria: Administracja i Zarządzanie, nr 101, Siedlce.

Sopińska A., Mierzejewska W., 2016, Zasobowe uwarunkowania otwartych innowacji, [w:] Zarzadzanie strategiczne w teorii i praktyce, red. A. Kaleta, K. Moszkowicz, A. Witek-Crabb, Prace Naukowe Uniwersytetu Ekonomicznego we Wrocławiu, nr 444, Wrocław.

Stachowiak K., Tomczak P., 2015, Przestrzenny wymiar sektora kreatywnego, Bogucki Wyd. Naukowe, Poznań.

Szultka S., 2012, Klastry w sektorach kreatywnych - motory rozwoju miast i regionów, PARP, Warszawa.

Wróbel D., 2013, Wpływ sektorów kreatywnych na rozwój instrumentów finansowych, [w:] Kultura, kreatywność i biznes - wyzwania dla polityki regionalnej, red. K. Janasz, S. Bąkowska, J. Markiewicz, M. Tomczyk, Zeszyty Naukowe Uniwersytetu Szczecińskiego, nr 793, Ekonomiczne Problemy Usług, nr 107.

\section{Źródla internetowe}

http://klasterdizajnu.pl.

http://www.pi.gov.pl/Klastry/chapter_95922.asp.

http://www.poligrafia.leszno.eu.

https://klaster.biz.

Policy handbook on promotion of creative partnerships. European agenda for culture, 2014, http:// ec.europa.eu/assets/eac/culture/library/reports/creative-partnerships_en.pdf. 